\title{
Sustainable Land Management and Added Value Enhancement of Agricultural Superior Commodities
}

\author{
Sri Jumiyati1 ${ }^{*}$, Rajindra1 ${ }^{1}$ A. Nixia Tenriawaru ${ }^{2}$, Abdul Hadid $^{3}$, Darwis $^{2}$ \\ ${ }^{1}$ Muhammadiyah University of Palu, Indonesia \\ 2 Hasanuddin University, Indonesia \\ ${ }^{3}$ Tadulako University, Indonesia \\ *Corresponding author e-mail: srijumiyati1068@gmail.com
}

\author{
How to Cite: Jumiyati, S., Rajindra., Tenriawaru, A.N., Hadid, A., \& Darwis. (2017). \\ Sustainable Land Management and Added Value Enhancement of Agricultural Superior \\ Commodities, Int. J. Agr. Syst. 5(2): 198-206.
}

\begin{abstract}
Cocoa and candlenuts are prime plantation crops of Central Sulawesi, Indonesia, especially Sigi Regency. They have comparative advantages, among others, due to the availability of land that has not been utilized optimally and is in the area with a support climate and the availability of labor. In addition, it also has a competitive advantage in the form of product price competitiveness in local, national and international markets. The management of land must be adapted to the sustainable and sustainable energy sector in sovereignty. This study aims to recommend and analyze the optimization of land management models that implement conservation techniques by cocoa agroforestry with candlenuts. The study employed Linier Programming Method. The results show that optimizing of farmers income by agroforestry pattern of cocoa is higher than the monoculture of cocoa. Recommended innovation of planting patterns models is expected to further optimize the efficiency of sustainable land management by farmers around the forest. Sustainable land management strategies by cultivating cacao and candlenut crops through agroforestry patterns can also increase the added value Income at the farm level by IDR. 2,625/kg or $65.6 \%$ is due to more acceptance and lack of production and marketing costs as well as output quantities, output prices.
\end{abstract}

Copyright $(\mathcal{O} 2017$ IJAS. All rights reserved.

Keywords:

Land management; sustainable; added value

\section{Introduction}

The plantation sub-sector has a comparative advantage when compared to the other sub-sectors, partly due to the availability of land that has not been utilized optimally and is in a region with a favorable climate and the availability of manpower. Artianingsih (2012) and Atmaja (2002) stated that during the economic crisis proves the toughness of the estate sub-sectors with an ever-positive economic growth (3.1\%). This condition also strengthens the competitive advantage in the form of price competetiveness of Indonesian plantation products in the world market and a strong reason to always cultivate and develop plantation products. They have a strategic role in giving government intervention dealing with superior commodity and poverty reduction, 
including common factors responsible for the poverty itself that requiring general policy options in national government level (Arsyad et al., 2014).

The cacao plantation in Central Sulawesi Province is generally similar to other areas outside Java, namely monoculture and mixed plantation. This is not inseparable from the characteristics of farmers in this region that has a diversity in the pattern of farming. Cacao crops in Sigi Regency are mostly cultivated in smallholder plantations by small-scale local farmers and the management is still traditional, as there is no cultivation in PBN or PBS (Jumiyati, 2012). Dinas Perkebunan Sulawesi Tengah mentioned that cocoa area area in Central Sulawesi area is about 289.274 ha spread in 13 regencies and cities with production reach 158,278 tons/year. In addition to cocoa, farmers of Central Sulawesi, especially farmers of Sigi also develop candlenut plants because of soil conditions and climate is very supportive. Sigi Regency gets the largest plantation development allocation is 7,150 ha because its area adjacent to Special Economic Zone (KEK) of Palu City which will become the location of processing industry of product (Anonymous, 2017).

Research Institute of Medicinal Plants and Aromatherapy Department of Agriculture informs in the trade between candlenut countries known as candleberry, Indian walnut and candlenut. The tree is called as varnish tree or Kukui nut tree (Widyaningsih and Diniyati, 2010). Anonymous (2011), mentioned that oil extracted from the seeds is useful in the industry for use as a mixture of paints and is known as tung oil. The waste from the oil treatment can be used for animal feed and crop fertilizer because it contains high Nitrogen, Phospor and Potas (NPK) elements (Hadi and Rodame, 2011). In addition, the candlenut tree can function as a soil and water conservation crop especially in watershed (DAS) and oblique or steep terrain (Anonymous, 2016).

Sigi farmers who are mostly cocoa farmers grow candlenuts because they can provide additional income from the sale of candlenuts that can be used to buy daily necessities before harvesting cocoa. Candlenut is also a protective tree for cacao plants with a planting process that is not difficult and can grow without fertilizer. The candlenut plant has the advantage one of which is the production cost is not too high as well as cocoa and cloves.

Hasibuan (2012) states that efforts to increase the production and productivity of cacao and candlenut plants in addition to intensification of agricultural land is the use of forest land and marginal land. Under such conditions, the application of agroforestry system is a solution for increasing production and income for the achievement of the welfare of farmers around the sustainable forest (Irwanto, 2008). Budiasa (2011) adds agroforestry as a land management technique that incorporates a combination of forest trees with agricultural crops as an innovative model of land use that is more efficient in land use and production inputs that aims to optimize production and income pe runit area that refers to the principle of the results sustainable. Kusnadi, Fariyanti, Rahmina and Jahroh (2009), because the candlenut commodity is the industrial raw materials needed in large quantities, then the development strategy with attention to the marketing aspects of production also need to be prioritized. Sudiyono (2004), explains that each distribution process involves different marketing institutions, different values and advantages. It's expected that this research can be a reference that will increase the interest and motivation of farmers in cultivated, processing and distribution (marketing) of plantation commodities to increase added value products in the form of increasing income and profit of farmers and sustainability of farming. This study aims to recommend and analyze the 
optimization of land management models that implement conservation techniques by cocoa agroforestry with candlenut.

\section{Materials and Method}

Basic consideration regarding optimization of sustainable land management with agroforestry system presented on figure 1 :

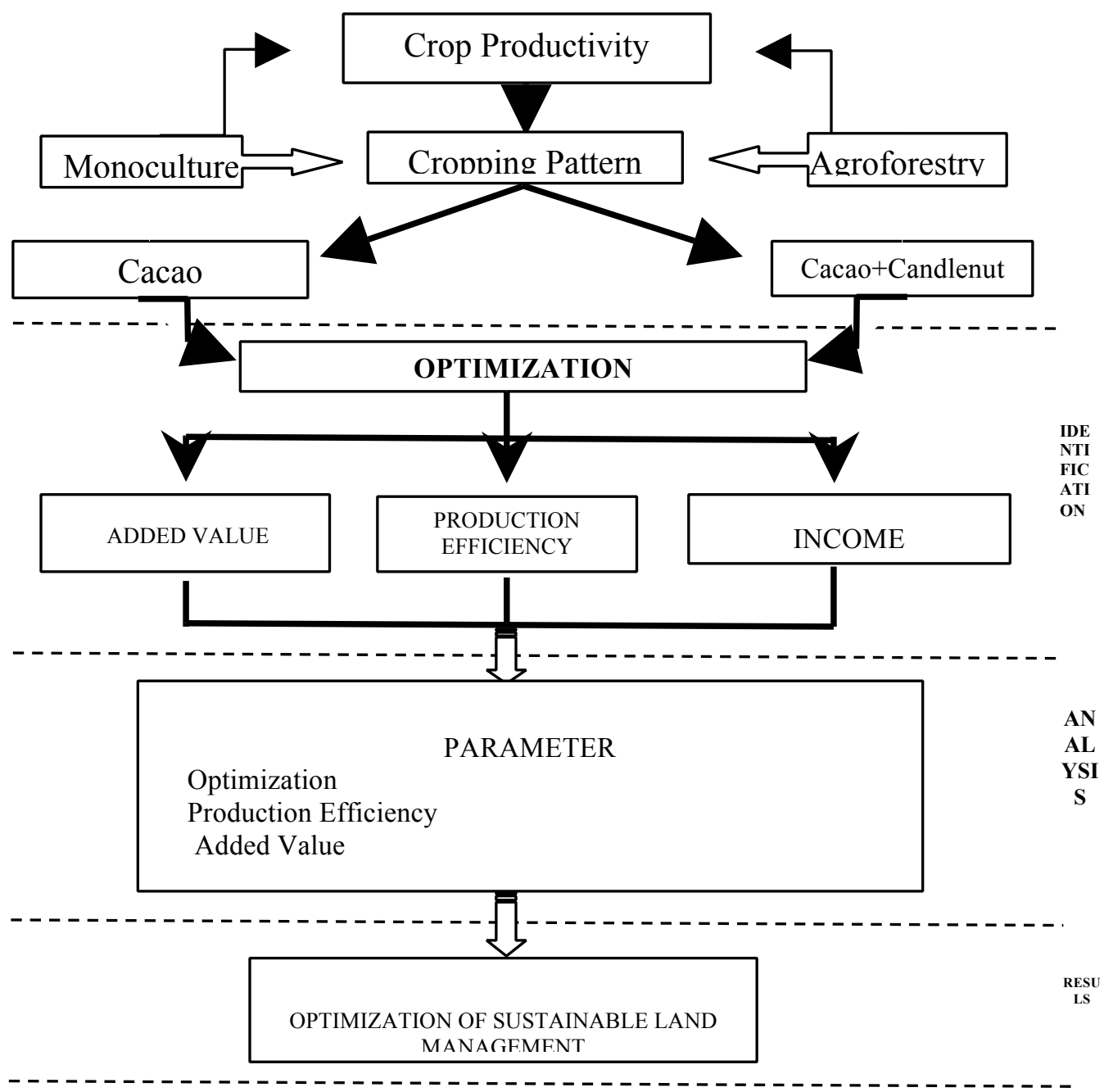

Figure 1. Research Framework

Plant productivity is determined by farming techniques applied by farmers, with the aim of increasing the income of monoculture cropping pattern in the short term managed to increase productivity and farmers incomes. However, in the long term can damage the environmental sustainability.

The new paradigm of land management not only prioritizing the economic aspect but also environmental aspect causes the farmer to take decision to apply agroforestry cropping pattern which can increase income through efficient of production process and environmentally friendly as well as to provide added value for farmers. Djajadiningrat, Hendriani and Famiola (2011), sustainable land management optimization efforts are carried out by internalizing the environment into resource management and business activities in agriculture. 


\subsection{Research Site and Sample}

Determination of research location in this research is done intentionally, by selecting research area based on certain purpose, which is deemed appropriate with research purpose. The selected research site is Sigi District, Central Sulawesi Indonesia especially Palolo Subdistrict because it is located in the vicinity in Lore-Lindu National Forest Buffer Area. The time required in conducting research for 3 (three) months (August until October 2016). Determination of respondents conducted by using purposive sampling technique is the determination of farmers respondents with monoculture cocoa 35 respondents and farmers agroforestry cocoa with candlenuts 15 respondents with a land area of $4 \mathrm{ha} /$ farmers for each farming system.

\subsection{Data Collection and Analysis}

The type of data collected is primary data through farmers and secondary data through government and other relevant sources. Based on the formulation of the problem, the data analysis will be used to answer the problem is by using Mathematical Programming (MP) especially Linear Programming (LP) because it is a method to analyze farming that support the achievement of goal (maximize income or minimize risk). Mathematically, linear programming issues are generally expressed as follows (Cohen and Cyert, 1976 in Budiasa, 2011):

Maximize objective function (income) $\max$

$$
Z_{\text {Max }}=\sum_{o e=1}^{n} \quad C_{o} X_{e},
$$

$X_{e}=$ Decision Variable (optimum income) product of farming

$C_{o}=$ Parameter of objective function (income of farming)

With constraint:

$$
\sum_{j=1} \quad a_{o} X_{e}=b_{o}
$$

$a_{o} X_{e}=$ parameter of constraint function for decision variable $\mathrm{e}$

$b_{i} \quad=$ constraint capacity o

Added value and income analyzed by using Hayami Method (1987) dalam Pardani (2012), with the calculation procedure in Table 1.

\begin{tabular}{|c|c|c|}
\hline No. & Value Added Variable & Value \\
\hline I. & Output, Input, Price & \\
\hline 1. & Output (kg) & A \\
\hline 2. & Raw Material Input (kg) & B \\
\hline 3. & Conversion Factor & $\mathrm{C}=\mathrm{A} / \mathrm{B}$ \\
\hline 4. & Labor Input (HKP) & $\mathrm{D}$ \\
\hline 5. & Labor Coefficient & $E=D / B$ \\
\hline 6. & Output Price (IDR/kg) & $\mathrm{F}$ \\
\hline 7. & Average Wage of Labor (IDR/HKP) & G \\
\hline II. & Value Added and Income & \\
\hline 1. & Raw Material Input Price (IDR $/ \mathrm{kg}$ ) & $\mathrm{H}$ \\
\hline 2. & Another Input Donations (IDR/kg) & I \\
\hline 3. & Output Value (IDR/kg) & $\mathrm{J}=\mathrm{DxF}$ \\
\hline 4. & Value Added (IDR/kg) & $\mathrm{K}=\mathrm{J}-\mathrm{H}-\mathrm{I}$ \\
\hline 5. & Value Added Ratio (\%) & $\mathrm{L}=\mathrm{K} / \mathrm{J} \times 100 \%$ \\
\hline 6. & Labor Income (IDR/kg) & $\mathrm{M}=\mathrm{ExG}$ \\
\hline 7. & Part of Labor (\%) & $\mathrm{N}=\mathrm{M} / \mathrm{K} \times 100 \%$ \\
\hline 8. & Income (IDR/kg) & $\mathrm{O}=\mathrm{K}-\mathrm{M}$ \\
\hline 9. & Income Level (\%) & $\mathrm{P}=\mathrm{O} / \mathrm{J} \times 100 \%$ \\
\hline
\end{tabular}

Table 1. Added Value Analysis of Hayami Method 
Hayami et al, (1987) in Pardani,(2012).

$\mathrm{A}=$ output/total of candlenuts sold by the trader

$\mathrm{B}=$ yield of candlenuts purchased by the trader

$\mathrm{D}=$ labor used in the marketing/distribution process

$\mathrm{F}=$ price of candlenuts which is valid at one period of analysis

$\mathrm{G}$ = average wage received by the worker at one period of analysis calculated with Working Day of Men (HKP)

$\mathrm{H}=$ price of candlenuts $/ \mathrm{kg}$ at the period of analysis

I = other costs such as packaging cost and transportation cost.

\section{Results and Discussion}

\subsection{Optimization of Land Area}

Cocoa farming activities by converting forest areas, although financially feasible but can not be denied can lead to the loss of various potential forests that can cause various environmental impacts. Cocoa cultivation that is integrated with tree / timber plants causes the function of forest to gradually recover temporarily in the cocoa cultivation in monoculture there will be permanent loss of forest function (Rianse, 2010).

Agroforestry is a form of land management to overcome land availability and increase land productivity. The problem that often a rises is the transfer of land to forest land is reduced. In addition, agroforestry is applied to be able to overcome the problem of availability and food security (Lahjie, 2003). Thus, agroforestry is an optimal method of land use based on sustainability principle, in a forest area or outside area in order to achieve sustainable farmers welfare (Mahendra, 2009).

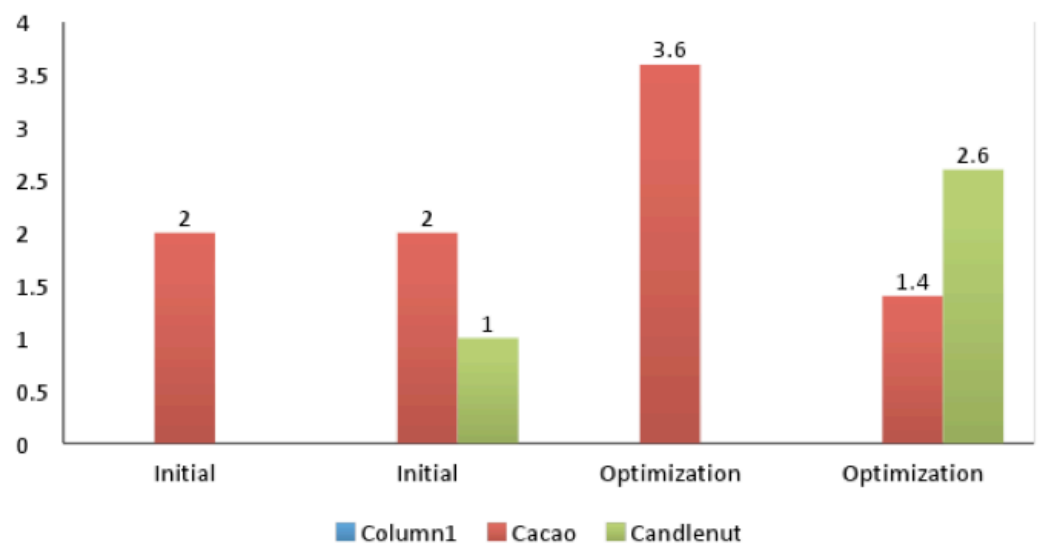

Figure 2. Optimization of Land (ha)

The above figure shows that the optimization of 4 ha of land use for cocoa monoculture is by adding the land area from 2 ha to 3.6 ha while for the agroforestry of cocoa and candlenut is to decrease the area of cocoa from 2 ha to 1.4 ha and increase the area of candlenut 1 ha to 2.6 ha. The results show that land use of agroforestry cocoa and candlenut can optimize land area and ensure the sustainability of both economic and ecological aspects.

\subsection{Optimizing Revenue}

Farmers surrounding the forest in general tend to choose to invest with low risk and minimal cost. Agroforestry as a cultivation strategy makes a farmers working on their own land can minimize the risk and increase income while getting sustainable environmental benefit. Khususiyah and Suyanto (2015) mentioned that the main risks 
faced by rural farmers are crop failures and price fluctuations of one type commodities. Through the application of agroforestry pattern farmers have a chance, if one type of crop failure and the fall of price, there is hope in other crop.

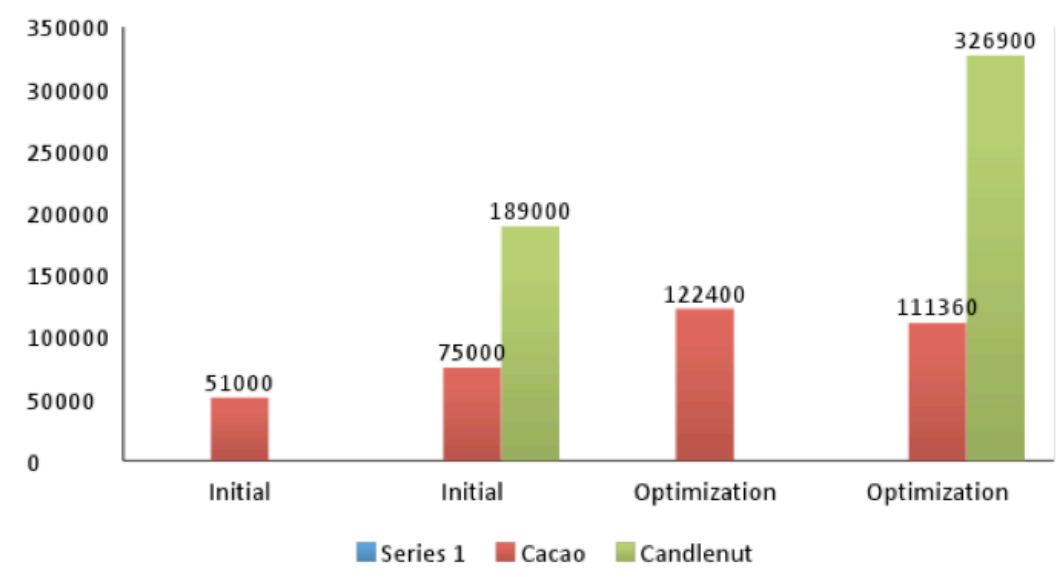

Figure 3. Optimization of Income x 1000 (IDR)

Farmers income is calculated within the last one year based on sales for every farmland managed by farmers. Based on the results of the research presented (Figure 3 ), it shows that the acceptance of cocoa monoculture farming is IDR. 122.4 million while for agroforestry cocoa with candlenut obtained from cocoa IDR. 111.4 million and from candlenut increased to IDR. 326.9 million with a total receipts of 438.3 million. It can be said that with the change of land management pattern, then agroforestry farmers have income about four times compared to farmers who apply cocoa monoculture pattern.

\subsection{Efficiency of Using Production Input}

At the time of farmers to optimize the farming system with agroforestry pattern, it will have an impact on the efficiency of using production input, for more details in Table 2.

Farmers of cocoa monoculture tend to be inefficient in using production input due to limited knowledge of farmers and a desire to increase production while cacao plants are over 15 years old with decreasing productivity. Through agroforestry pattern of farm management can be more efficient both technically and economically through production cost savings. At the time of optimization of farming, production input used are not all used so that there is remaining inventory. Conversely, if the production input is used up then it will have an effect on the addition of optimal acceptance value for every 1 unit of production input. 
Table 2. Efficiency of Using Production Input

\begin{tabular}{lccc}
\hline \multicolumn{1}{c}{ Input Production } & Stock & Use & Stock left \\
\hline Land (ha) & 4 & 4 & 0 \\
Seedlings (tree) & 2600 & 800 & 1800 \\
Seed (kg) & 2000 & 1750 & 250 \\
Making of Holes (HOK) & 40 & 30 & 10 \\
Planting (HOK) & 55 & 45 & 10 \\
Manure (kg) & 20000 & 10000 & 10000 \\
Insecticide (liter) & 44 & 39 & 5 \\
Maintenance 3x/Year (HOK) & 2850 & 2700 & 150 \\
NPK (kg) & 2000 & 1900 & 100 \\
UREA (kg) & 1550 & 1400 & 150 \\
KCL (kg) & 800 & 700 & 100 \\
TSP (kg) & 1100 & 1050 & 50 \\
Thinning (HOK) & 31 & 30.5 & 0.5 \\
Harvesting of Cacao (HOK) & 3700 & 3500 & 200 \\
Harvesting of Candlenut (HOK) & 270 & 270 & 0 \\
\hline
\end{tabular}

\subsection{Added Value and Income}

Soekartawi (2000), agroindustry activities that can add value to agricultural commodities are processing and marketing activities. Factors that can affect added value are technical and market factors. The influential technical factors are production capacity, quantity of raw materials and labor. While the influential market factors are the price of labor wages, price of raw materials and other input value besides raw materials and labor. Stanton (2010), activities to increase added value in its operations also require costs to be incurred by agricultural actors. The added value is derived from the reduction of output value with input prices and other input contributions. The average value-added marketing of candlenut at the farmers level listed on Table 3.

Table 3. Added Value of Candlenuts

\begin{tabular}{clrr}
\hline No. Analysis Variable & Farmer & $\begin{array}{c}\text { Collecting Traders } \\
\text { in Province }\end{array}$ \\
\hline I. & Output, Input, Price & & \\
1. & Output (kg) & 2.049 & 28.697 \\
2. & Raw Material Input (kg) & 2.049 & 28.697 \\
3. & Conversion Factor & 1 & 1 \\
4. & Labor Input (HKP) & - & 31 \\
5. & Labor Coefficient & - & 0,001 \\
6. & Output Price (IDR/kg) & 4.000 & 4.500 \\
7. & Average Wage of Labor (IDR/HKP) & - & 50.000 \\
\hline II. & Added Value and Income & & \\
1. & Raw Material Input Price (IDR/kg) & 1.375 & 4.000 \\
2. & Another Input Donations (IDR/kg) & - & 95 \\
3. & Output Value (IDR/kg) & 4.000 & 4.500 \\
4. & Added Vallue (IDR/kg) & 2.625 & 405 \\
5. & Added Value Ratio (\%) & 65,6 & 9,0 \\
6. & Labor Income (IDR/kg) & - & 50 \\
7. & Part of Labor (\%) & - & 12,35 \\
8. & Income (IDR/kg) & 2.625 & 355 \\
9. & Income Level (\%) & 65,6 & 7,9 \\
\hline & & & \\
\hline
\end{tabular}


Increase added value at the farmers level is IDR $2.625 / \mathrm{kg}$ or $65.6 \%$ and the trader at the provincial level is IDR. $405 / \mathrm{kg}$ or $9.0 \%$. The greatest added value is found in the farmers because it is reduced by the not so substantial production cost that the farmer devotes to his farm. While for traders collectors at the provincial level is the value of output after reduced input prices and marketing costs (sack price and loading costs). Revenue are earned on the basis of the calculation of added value after deducting the labor income. Added value and Income at the farm level are the same as not involving the labor force while the profits at the provincial collector merchant are reduced from the added value due to the reduced labor income. The average value of farmers income is IDR. $2.625 / \mathrm{kg}$ or $65.6 \%$, while the provincial collector traders have lower income than the added value of IDR. $355 / \mathrm{kg}$ or $7.9 \%$.

\section{Conclusion}

Land management with agroforestry pattern cocoa integrated with candlenut plantation based on technical and economical reasons can optimize land management. Agroforestry pattern can be used as a solution to solve the problem of land constraints and efficient use of production inputs and prospective from financial aspect as both types of plant have market guarantee of stable and acceptable product from the sociocultural aspects of local farmers. Marketing candlenuts provides the highest added value and the highest income is at the farm level due to more acceptances and lack of production and marketing costs as well as amount and price of output.

\section{References}

Anonymous, (2011). Aspek Pemasaran Agribisnis Pertanian dan perkebunan. http:// petunjukbudidayablogspot.co.id. Accessed on March 4, 2017.

Anonymous, (2016). Peran Perkebunan dalam Perekonomian Nasional. http:// ditjenbun pertanian.go.id. Accessed on March 3, 2017.

Anonymous, (2017). Kakao Primadona Sulawesi Tengah. Antara Sulteng.com. Accessed on July 28, 2017.

Arsyad, M., A. Nuddin, M.Y. Zamhuri, S. Yusuf, (2014). The Poverty Reality of Coastal and Agriculture: How Severe the Seaweed Farmers and Cocoa Smallholders. International Journal of Agriculture System, 2(2):119-131.

Artianingsih, S. (2012). 19 Peluang Investasi Kayu, Tanaman Perkebunan dan Tanaman Buah. PT. Agromedia Pustaka, Jakarta.

Atmaja, E. S. (2002). Ekonomi Pertanian Indonesia, CV. Angkasa, Bandung.

Budiasa, I. W. (2011). Pertanian Berkelanjutan dan Teori Permodelan. Udayana University Press, Denpasar.

Djajadiningrat, S. T., Hendriani, Y. and Famiola, M. (2011). Ekonomi Hijau (Green Economy). Rekayasa Sains, Bandung.

Hadi, A.Q., and Rodame M. N. (2011). 10 Tanaman Investasi Pendulang Rupiah. Penebar Swadaya, Jakarta.

Hasibuan A. (2012). Manajemen Perubahan Membalik Arah Menuju Usaha Perkebunan yang Tangguh Melalui Strategi Optimalisasi Efisiensi. Penerbit Andi, Yogyakarta.

Irwanto. (2008). Peningkatan Produktivitas Lahan dengan Sistem Agroforestri. ww.irwantoshut.com. Accessed on July 2, 2017..

Jumiyati, S. (2012). Perubahan Lahan menuju Optimasi Usahatani Hutan Rakyat di Kabupaten Parigi Moutong. Disertasi. Prodi Sosial Ekonomi dan Lingkungan Kehutanan, Fakultas Kehutanan Universitas Mulawarman, Samarinda. 
Khususiyah and Suyanto (2015). Kontribusi Agroforestri dalam Meningkatkan Pendapatan dan Pemerataan Pendapatan Masyarakat Pengelola Hutan Kemasyarakatan di Sesaot Lombok. Prosiding Seminar Agroforestri 2015. World Agroforestry Centre (ICRAF). Bogor, Indonesia.

Kotler, P. (2001). Manajemen Pemasaran di Indonesia. Analisis, Perencanaan, Implementasi dan Pengendalian. Salemba Empat, Jakarta.

Kusnadi, N., Fariyanti A., Rachmina D., and Jahroh S. (2009). Bunga Rampai Agribisnis. Seri Pemasaran. IPB Press, Bogor.

Lahjie, A. M. (2003). Pendekatan Pengusahaan Hutan dengan Sistem Agroforestri. Universitas Mulawarman Press, Samarinda.

Mahendra, F. (2009). Sistem Agroforestri dan Aplikasinya. Graha Ilmu, Yogyakarta.

Pardani, C. (2012). Kajian Nilai Tambah Agroindustri Nata de Coco. http:/ / agfarhoncblogspot.co.id. Accessed on March 16, 2017.

Rianse, U. (2010). Agroforestri Solusi Sosial dan Ekonomi Pengelolaan Sumberdaya Hutan. Penerbit Alfabeta, Bandung.

Soekartawi, (2000). Agroindustri dalam Perspektif Sosial Ekonomi. PT. RajaGrafindo Persada, Jakarta.

Stanton, W.J. (2001). Prinsip Pemasaran. Erlangga, Jakarta.

Subadi. (2010). Penguasaan dan Penggunaan Tanah Kawasan Hutan. Prestasi Pustakaraya, Jakarta.

Widyaningsih, T. S and Diniyati, D. (2010). Kontribusi Ekonomi dan Sistem Pemasaran Hasil Hutan Rakyat Pola Manafarma Majenang. Jurnal Penelitian Sosial dan Ekonomi Kehutanan Cilacap. Vol. 7 No. 1 Maret 2010. 